\title{
DOBLE ESCALA SALARIAL Y CONSOLIDACIÓN DE DERECHOS ADQUIRIDOS
}

Fco. Ramón Lacomba Pérez

Abogado. Cuatrecasas

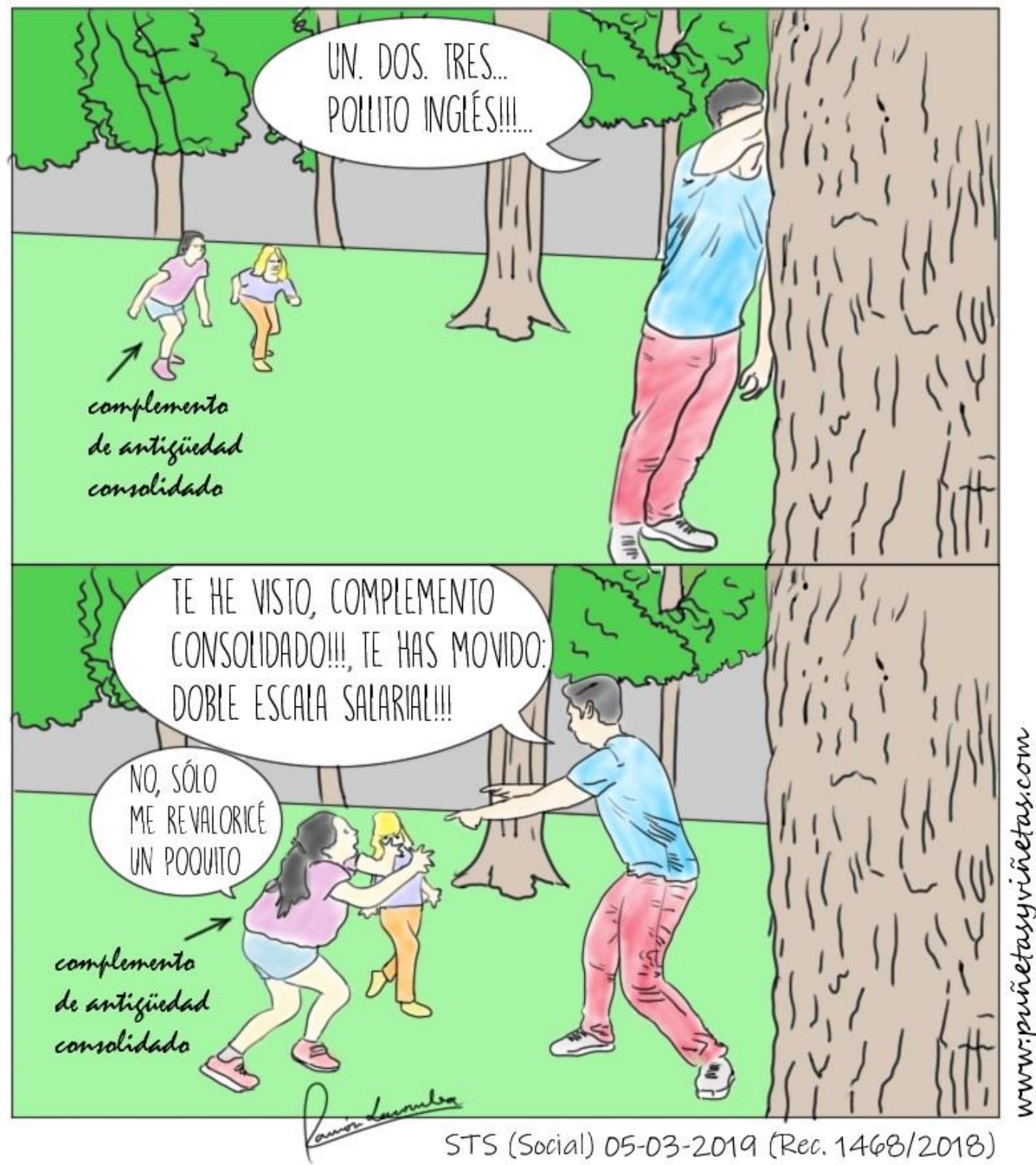

IUSLabor 1/2019, ISSN 1699-2938, p. 323-326

DOI. 10.31009/IUSLabor.2019.i01.10 
La STS (Social) 05-03-2019 (Rec. 1468/2018), que ilustramos con esta viñeta, responde a la siguiente pregunta: ¿Es correcta una doble escala salarial que mantenga de manera estática derechos adquiridos? ¿Y de manera dinámica (sin justificación objetiva)? Las respuestas son sí y no, respectivamente.

Desde antiguo, tanto el Tribunal Supremo como el Tribunal Constitucional vetan la posibilidad de que el convenio colectivo establezca diferencias retributivas entre los trabajadores por la sola y única circunstancia de su fecha de ingreso en la empresa, salvo que se aporte una justificación objetiva, razonable, y se trate de una diferencia equitativa y proporcionada, pues, en otro caso, resultaría contrario al principio de igualdad (artículo $14 \mathrm{CE}$ ).

Una de esas justificaciones objetivas admitidas es la consolidación de derechos ya adquiridos, pues, no constituye propiamente una doble escala salarial la diferenciación retributiva en función de la antigüedad en la empresa. Ahora bien, y tal y como se extrae de la STS objeto del presente comentario, con cita al efecto de la STS (Social) 10-11-2010 (Rec. 140/2009), no es lo mismo limitarse a establecer una compensación "estática" de esos derechos adquiridos hasta un determinado momento (congelándolos así) -lo que sí se admite-, que hacerlo de forma "dinámica", manteniendo en funcionamiento el complemento de antigüedad sólo para los trabajadores veteranos o, consolidándolo para éstos como complemento ad personam, pero estableciendo su revalorización anual, o el incremento, en función de tales años de antigüedad, de otras mejoras retributivas, tales como el complemento de la prestación por IT a cargo de la empresa, o la aportación al Plan de Pensiones, o por cambio de nivel.

El criterio jurisprudencial al respecto es contundente y reiterado: es posible esa garantía de los derechos adquiridos "de forma estática", en el sentido de limitarse a conservar los derechos ya reconocidos a los trabajadores en el momento en que se produce el cambio normativo (a modo de foto fija), pero no cabe hacerlo "de forma dinámica", manteniendo un régimen jurídico que puede determinar la aplicación en el tiempo de cantidades variables o actualizadas. En definitiva, constituye una doble escala salarial prohibida establecer sin justificación dos regímenes de antigüedad diferentes y abiertos al futuro: uno, en el que los años de antigüedad siguen generando ventajas (para los trabajadores veteranos) y otro, en el que los años de antigüedad que se vayan acumulando no suman a ningún efecto (para los trabajadores de nuevo ingreso). La Sentencia cita, además, la STS 21-10-2014 (Rec. 308/2013) y la STC 112/2017 de 16-10-2017, entre las más recientes.

Pese a ello, como vemos, siguen llegando al Tribunal Supremo controversias en esta materia, a lo que dan pie sentencias como la de contraste que se aporta (STSJ 
Andalucía, Sevilla, 23-11-2017, Rec. 356/2017), que no vio doble escala salarial prohibida en un supuesto tan evidente donde el convenio mantenía inalterable el devengo del complemento de antigüedad para los trabajadores ya contratados antes y lo excluía para los trabajadores de nuevo ingreso.

La Sala rechaza frontalmente este criterio y reitera su doctrina, confirmando la sentencia recurrida, que había declarado la existencia de doble escala salarial prohibida en este caso, tras constatar que, por parte de la empleadora no se han aportado indicios para intentar una justificación objetiva y razonable de la diferencia de trato entre unos u otros trabajadores en atención a la fecha de ingreso en la empresa.

Dos cuestiones adicionales queremos destacar a propósito de esta Sentencia:

1) De un lado, nótese que, en el supuesto analizado, aflora el argumento de la doble escala salarial con ocasión de una reclamación de cantidad tras el despido de la trabajadora demandante, derivado del despido colectivo acordado en la empresa con abono de una indemnización ya mejorada. Al respecto, debe tenerse en cuenta que, en estos casos, si se hubiera debatido sobre el cálculo de la indemnización por despido, el reconocimiento de la existencia de doble escala salarial habría supuesto la revisión del salario modulador de los efectos del despido, incrementando la indemnización resultante, pero no habría justificado otra calificación del despido comunicado, pues habría existido una discrepancia razonable, de acuerdo con el criterio de la STS 11-12-2012 (Rec. 3538/2011) (en el mismo sentido, en relación con un supuesto de doble escala salarial, ver STSJ Cantabria 12-07$\underline{2013}$, Rec. 175/2013).

2) Por otra parte, adviértase también que la STSJ recurrida ya señaló expresamente que, aunque dicha doble escala salarial prohibida se mantuvo en los sucesivos convenios colectivos, vigentes en los períodos 01-01-92 al 31-1296, 01-01-97 al 31-12-00, 01-01-01 al 31-12-05 y 01-01-06 al 31-12-2012, este último vigente durante el despido de la actora, los mismos no fueron impugnados, por lo que los devengos (y no devengos, añadimos) realizados por los trabajadores en aplicación de los convenios no vigentes no pueden considerarse ni ilegales, ni ilegítimos, al no ejercitarse acción alguna para dejar sin efecto el percibo del citado complemento salarial, ni colectiva, ni individualmente. El convenio colectivo estatutario tiene naturaleza jurídica de norma temporal, que no despliega eficacia fuera del tiempo al que se contrae su vigencia (STS 25-06-1993, Rec. 1345/1992). A este respecto, es 
de interés recordar la relevante STS 28-11-2018 (Rec. 193/2015), Caso CLH, donde sí fue impugnado el convenio colectivo inicial. 